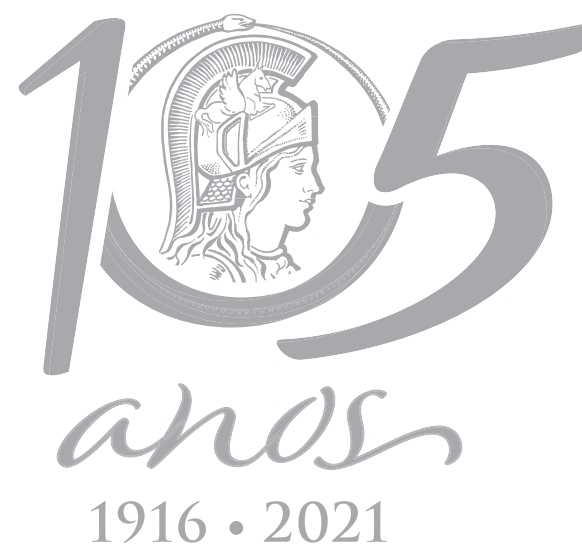

\title{
ECOSYSTEMS
}

\section{Population structure and growth of two opulations of Aegla Schmitti Hobbs III, 1979 (Anomura, Aeglidae) in the eastern Paraná state, Brazil}

\author{
ANDRÉ TREVISAN, MURILO Z. MAROCHI \& SETUKO MASUNARI
}

\begin{abstract}
The population structure and growth of two populations (Arraial and Capivari rivers) of Aegla schmitti was evaluated. The following parameters were determined: size, age structure, sex ratio, recruitment period, and sampling method selectivity (traps and handnet). There was variation between males and females. The carapace length size class distribution was unimodal in the Arraial River, and polymodal in the Capivari River. The sampling method influenced the proportion of demographic categories. The recruitment occurred mostly between October and December. The growth curves for the Arraial and Capivari rivers, respectively, were $\mathrm{Ct}=26,50[1-\mathrm{e}-0,004(\mathrm{t}+53,36)]$ and $\mathrm{Ct}=34,79[1-\mathrm{e}-0,0024(\mathrm{t}+122,34)]$ for males, and $\mathrm{Ct}=23,07[1-\mathrm{e}-0.0027(\mathrm{t}+23,18)]$ and $\mathrm{Ct}=25.52[1-\mathrm{e}-0,0033(\mathrm{t}+19,51)]$ for females. The maximum $\mathrm{CL}$ estimated for males and females were 26.50 and $23.07 \mathrm{~mm}$ for the Arraial River, and 34.79 and $25.52 \mathrm{~mm}$ for the Capivari River. Longevity was estimated in 2 years for females of both populations, and 2.5 and 3 years for males of the Arraial and Capivari rivers, respectively. The results allow for the characterization of the growth patterns of $A$. schmitti in two hydrographic basins, providing information for the species' preservation and also demonstrating the selectivity of the different sampling methods used for aeglids.
\end{abstract}

Key words: Population growth, recruitment, sex ratio, size composition, von Bertalanffy model.

\section{INTRODUCTION}

Studies concerning the dynamics and structure of crustacean populations are important, as they allow for an increased knowledge of the ecological diversity of ecosystems and the biological strategies of organisms when facing their environments. Similarly, studies on animal growth provide important biological information for the comprehension of a given group's biology, such as growth rates, longevity, population sizeclass structure, among others (Margalef 1983, Baptista et al. 2003, Branco \& Fracasso 2004, Masunari 2006, Trevisan \& Santos 2011).
The species of the genus Aegla Leach, 1820 are the only representatives of the Infraorder Anomura that occur exclusively in continental waters. These crustaceans live under rocks and leaves in the bottom of rivers, streams, lakes and flooded caves. They are considered key elements in the trophic chains of aquatic ecosystems, given that they are consumed as food by fishes, birds, frogs and caimans; while aeglids themselves feed on decaying leaves and immature forms of aquatic insects, being important in the population control of these invertebrates (Burns 1972, Arenas 1976, Magni 
\& Py-Daniel 1989, Bond-Buckup \& Buckup 1994, Bueno \& Bond-Buckup 2004, Santos et al. 2008).

The first studies concerning Aegla were performed in the 1970's and dealt basically with issues of systematics and taxonomy, with highlights for the inventories of Argentinian species (Ringuelet 1949, Lopretto 1978a, b, 1979, 1980a, b) and the description of a few species from the Rio Grande do Sul state, Southern Brazil (Buckup \& Rossi 1979). A few years later, a taxonomic revision of the family Aeglidae was published by Bond-Buckup \& Buckup (1994), in which 20 new species were described. From the beginning of the $21^{\text {st }}$ century onwards, the advent of new molecular and morphological techniques resulted in the description of more than 20 additional new species. Currently, the genus is comprised by 85 formally described species, with new descriptions being expected in the following years (Santos et al. 2017, Jara et al. 2018, Paéz et al. 2018).

In the last decades, there is a growing number of publications bringing new information regarding the biology and population structure of aeglids (Bahamonde \& López 1961, López 1965, Rodrigues \& Hebling 1978, Bueno \& BondBuckup 2000, Swiech-Ayoub \& Masunari 2001a, b, Noro \& Buckup 2002, Fransozo et al. 2003, Colpo et al. 2005, Gonçalves et al. 2006). More recently, new approaches have been incorporated in the investigation of population parameters, including population size estimation (Bueno et al. 2007) and the genetic structure and diversity of populations (Bartholomei-Santos et al. 2011, Zimmermann et al. 2019). Despite this, traditional approaches were not abandoned and may still bring important contributions (Cohen et al. 2011, Trevisan \& Santos 2012, Marçal et al. 2018).

Similar to the case of the studies on population dynamics and structure, investigations in the topic of animal growth, based in the von Bertalanffy (1938) models, have also received considerable attention in recent years, with highlights to the studies performed with Aegla platensis Schmitt, 1942 (Bueno et al. 2000), Aegla leptodactyla Buckup \& Rossi, 1979 (Noro \& Buckup 2003), Aegla jarai Bond-Buckup \& Buckup, 1994 (Boos Jr et al. 2006), Aegla longirostri Bond-Buckup \& Buckup, 1994 (SilvaCastiglioni et al. 2006), Aegla itacolomiensis Bond-Buckup \& Buckup, 1994 (Silva-Gonçalves et al. 2009), Aegla paulensis Schmitt, 1942 (Cohen et al. 2011), Aegla manuinflata Bond-Buckup \& Santos, 2009 (Trevisan \& Santos 2011) and Aegla schmitti (Chiquetto-Machado et al. 2016).

In this study, we described the structure of two populations of Aegla schmitti Hobbs III, 1979, including aspects of the size class distribution frequency, sex ratio and recruitment period. Besides this, we also determined parameters related to population growth by using the von Bertalanffy model (1938) and tested for sampling bias regarding the capture methods used. From our results and those of previously published studies concerning Aegla species, we discussed aspects of the life cycle, reproductive biology and intra-/interspecific variability in aeglids. Additionaly, the bias of each sampling method is discussed.

\section{MATERIALS AND METHODS}

Animals were sampled monthly from March 2009 to February 2010, in two rivers belonging to the Atlantic Basin of the Paraná State: the Arraial River, which belongs to the Coastal micro-basin and drains into the Atlantic Ocean, in the coast of the Paraná State; and the Capivari River, which belongs to the Ribeira do Iguape microBasin, and also drains into the Atlantic Ocean, in the coast of the São Paulo State (Maack 1968, Bigarella 1978) (Figure 1). 

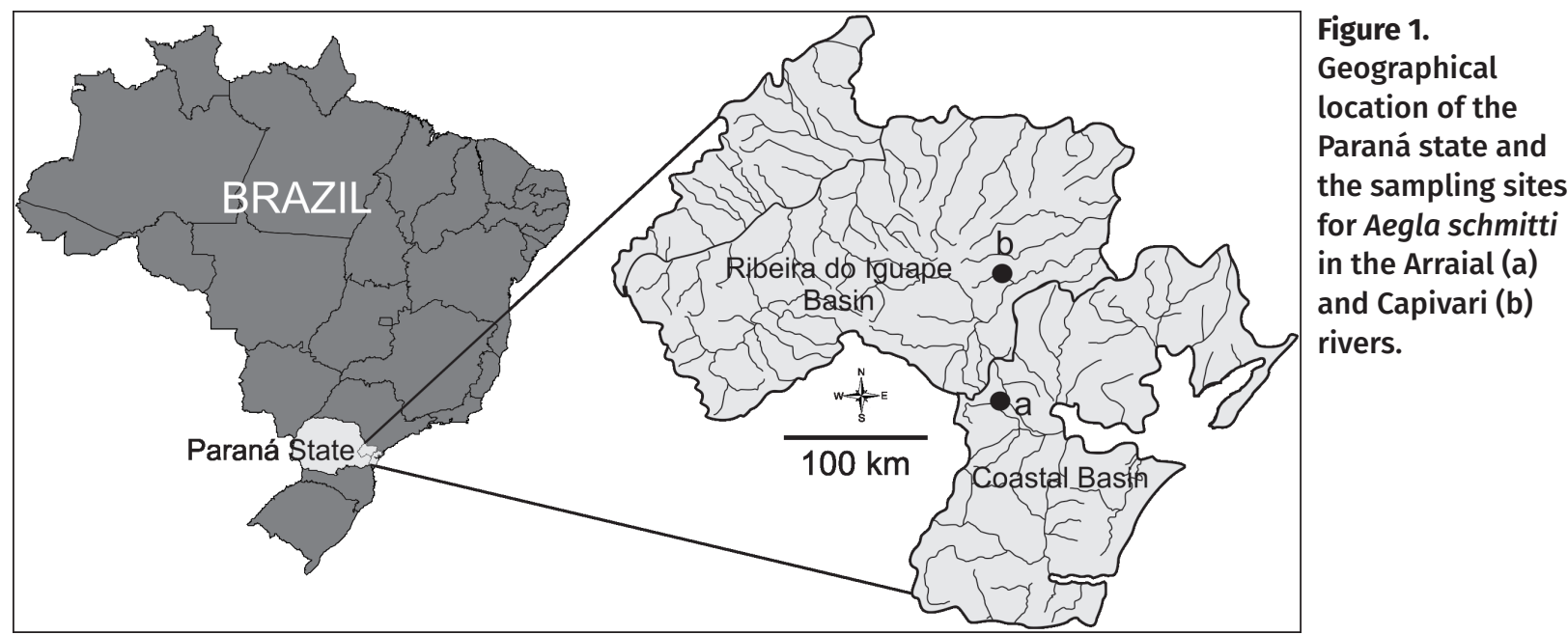

The temperature $\left({ }^{\circ} \mathrm{C}\right)$, dissolved oxygen $(\mathrm{mg} / \mathrm{L})$, oxygen saturation (\%), water conductivity $(\mu \mathrm{S} / \mathrm{cm})$ and hydrogen potential $(\mathrm{pH})$ were measured with an oxygen meter (Lutron D05510) monthly from March 2009 to February 2010 in both rivers (Martinelli \& Krusche 2004). The abiotic variables of each river were compared through an ANOVA.

The samplings were made with the aid of minnow traps baited with bovine liver, and complemented with handnet sampling ( $40 \times 60$ $\mathrm{cm}$ grid, $1 \mathrm{~mm}$ mesh size). The traps remained in the water for approximately 12 hours (from the late afternoon to the morning of the following day), and the sampling effort for the hand net was of one person/20 min for each sampling event.

The sampled aeglids were sexed through the visualization of pleopods in females and their absence in males, and/or by visualization of the genital openings (in the coxa of the $3^{\text {rd }}$ pereopod in females, and in the coxa of the $5^{\text {th }}$ pereopod in males) (Trevisan \& Santos 2011). When visualization of the pleopods was not possible, a portable magnifying glass was used to check the position of the genital pores. Individuals with carapace length $(\mathrm{CL})$ below 3 $\mathrm{mm}$ were considered as unsexed juveniles, because neither the pleopods nor the genital pores were developed enough to allow for an accurate sex identification. Following this procedure, the animals had their carapace length $(\mathrm{CL})$ measured, from the tip of the rostrum to the posterior edge of the carapace, by using a digital caliper $( \pm 0,01 \mathrm{~mm})$, after which they were released back into their collection sites.

Sexually immature males had $C L$ values below 10.94 and $11.14 \mathrm{~mm}$, while sexually immature females had CL values below 10.62 and $9.92 \mathrm{~mm}$, for the Arraial and Capivari rivers, respectively. The minimum mean and maximum size of the captured animals was determined. The median values of males and females of both rivers were compared with a Mann-Whitney test (Zar 1996). The influence of the sampling method (minnow traps or handnet) were tested within each age-class, in each river, with a Student's t-test.

The sex ratio along the months of the year was evaluated in three different ways: the first considering all the sampled animals with both sampling methods (grouped data), the second considering only the individuals caught with a handnet, and the third considering only the individuals caught in traps. This procedure was adopted to evaluate a possible sampling bias 
resulting from behavioral differences between male and female aeglids. For this population parameter, a Chi-square test was used, with an expected proportion of 1:1 (Snedecor \& Cochran 1967).

For the study of population structure, the sampled population was distributed in size classes at each $1 \mathrm{~mm}$ of CL (Zar 1996). For the analyses of sex ratio within each CL size class, a Chi-square test was used (Snedecor \& Cochran 1967). The normality of each of these distribution data was analyzed with a Shapiro-Wilk test (Zar 1996).

The recruitment period of the population was determined according to the presence of early-stage juveniles in each season of the year. To test for differences in the proportion of juveniles among the seasons, an ANOVA was performed (Colpo et al. 2005).

The growth of males and females, measured via their CL, was estimated separately via the displacement of the modes obtained in the frequency distribution histograms, along each sampling month (Macdonald \& Pitcher 1979, Macdonald 1987). In this analysis, the animals of the Arraial River were separated in classes at each $1 \mathrm{~mm}$ of $\mathrm{CL}$, and those of the Capivari River at each $1.5 \mathrm{~mm}$ of $\mathrm{CL}$, as per determined by one quarter of the data's standard deviation (Markus 1971). Animals with CL below $3 \mathrm{~mm}$ were summed to both the male and female datasets for the analysis of distribution in size class frequencies.

The modes of the $C L$ frequency histograms were calculated separately for each sex and sampling site, following Spiegel (1979): MODE = $L_{1}+\left[\Delta_{1} / \Delta_{1}+\Delta_{2}\right] * C$, where: $L_{1}=$ real inferior limit of the modal class (the one that contains the mode); $\Delta_{1}=$ excess of the modal frequency over the immediately inferior class; $\Delta_{2}=$ excess of the modal frequency over the immediately superior class; and $\mathrm{C}=$ range of the modal class interval.
The growth model used in this study was the one proposed by von Bertalanffy (1938), which corresponds to the following mathematical equation: $C_{t}=C_{\alpha}\left[1-e^{-k(t+t)}\right]$, where: $C_{t}=$ mean carapace length of individuals in age $t$, in $\mathrm{mm}$; $\mathrm{C}_{\infty}=$ mean maximum carapace length, in $\mathrm{mm} ; \mathrm{k}$ = parameter related to the growth rate, referring to days; $\mathrm{e}=$ base of the natural logarithms; $\mathrm{t}=$ age of the individuals, in days; $t_{0}=$ parameter related to the length of the animal at its birth.

The growth curves were linearized according to Allen (1976) and compared using a covariance analysis (Snedecor \& Cochran 1967). In this test, three hypotheses were evaluated: $1^{\text {st }}$ hypothesis of the homogeneity of the residual variances; $2^{\text {nd }}$ hypothesis of equality between the slope and elevation of the lines of males and females; and $3^{\text {rd }}$ hypothesis of equality between the line intercepts of males and females.

All analyses were performed in BIOSTAT (Ayres et al. 2007) with a confidence interval of 95\%.

\section{RESULTS}

In general, the water temperature, oxygen saturation and hydrogen potential was higher in Capivari river throughout months and differ among rivers (Table I). On the other hand, the water conductivity was higher in Arravial river (Table I). The percentage of dissolved oxygen was similar among rivers (Table I).

A total of 2959 individuals was sampled during the twelve sampling campaigns. Being 2053 in the Arraial River (1193 males, 632 females, 209 ovigerous females and 19 unsexed juveniles) and 906 in the Capivari River (568 males, 304 females, 12 ovigerous females and 22 unsexed juveniles) (Table II).

The sampling methods used in this study showed selectivity regarding the age class 
Table I. ANOVA results and mean values for temperature, dissolved oxygen, oxygen saturation, water conductivity and hydrogen potential $(\mathrm{pH})$ comparison among Arraial and Capivari rivers.

\begin{tabular}{|c|c|c|c|c|c|c|c|c|c|c|c|}
\hline Months & River & $\begin{array}{c}\text { Temperature } \\
\pm \mathrm{SD}\left({ }^{\circ} \mathrm{C}\right)\end{array}$ & $\begin{array}{c}\mathbf{P} \\
\text { and F } \\
\text { values }\end{array}$ & $\begin{array}{c}\text { Dissolved } \\
\text { oxygen } \pm \\
\text { SD (mg/L) }\end{array}$ & $\begin{array}{c}\mathbf{P} \\
\text { and F } \\
\text { values }\end{array}$ & $\begin{array}{l}\text { Oxygen } \\
\text { saturation } \\
\pm \text { SD (\%) }\end{array}$ & $\begin{array}{l}P \text { and } \mathbf{F} \\
\text { values }\end{array}$ & $\begin{array}{c}\text { Water } \\
\text { conductivity } \\
\pm \mathrm{SD}(\mu \mathrm{S} / \mathrm{cm})\end{array}$ & $\begin{array}{l}P \text { and } \mathbf{F} \\
\text { values }\end{array}$ & $\begin{array}{c}\mathrm{pH} \pm \\
\mathrm{SD}\end{array}$ & $\begin{array}{c}\mathbf{P} \\
\text { and F } \\
\text { values }\end{array}$ \\
\hline March & \multirow{12}{*}{ Arraial } & $17.53 \pm 0.15$ & \multirow{25}{*}{$\begin{array}{l}0.02 \\
5.01\end{array}$} & $7.3 \pm 0.26$ & \multirow{25}{*}{$\begin{array}{l}0.84 \\
0.03\end{array}$} & $88.16 \pm 3.31$ & \multirow{25}{*}{$\begin{array}{l}0.03 \\
4.41\end{array}$} & $85.33 \pm 25.8$ & \multirow{25}{*}{$\begin{array}{c}<0.001 \\
41.73\end{array}$} & $\begin{array}{c}5.66 \pm \\
0.47\end{array}$ & \multirow{25}{*}{$\begin{array}{c}<0.001 \\
37.44\end{array}$} \\
\hline April & & $16.3 \pm 0.36$ & & $8.53 \pm 0.4$ & & $\begin{array}{c}100.59 \pm \\
5.45\end{array}$ & & $98.33 \pm 11.6$ & & $\begin{array}{c}5.64 \pm \\
0.5\end{array}$ & \\
\hline May & & $7.2 \pm 0.5$ & & $8.46 \pm 0.2$ & & $81.05 \pm 2$ & & $105.66 \pm 17.1$ & & $\begin{array}{c}5.4 \pm \\
0.12 \\
\end{array}$ & \\
\hline June & & $6.56 \pm 0.15$ & & $8.46 \pm 0.75$ & & $79.73 \pm 6.76$ & & $126.33 \pm 6.02$ & & $\begin{array}{c}5.17 \pm \\
0.09\end{array}$ & \\
\hline July & & $5.26 \pm 0.5$ & & $7.67 \pm 0.45$ & & $73.16 \pm 2.61$ & & $69.33 \pm 14.18$ & & $\begin{array}{c}6.12 \pm \\
0.33\end{array}$ & \\
\hline August & & $8.63 \pm 0.2$ & & $7.9 \pm 0.36$ & & $78.35 \pm 3.92$ & & $100.33 \pm 16.5$ & & $\begin{array}{c}5.48 \pm \\
0.24\end{array}$ & \\
\hline September & & $11.96 \pm 0.11$ & & $7.2 \pm 0.5$ & & $77.27 \pm 5.18$ & & $80 \pm 20$ & & $\begin{array}{c}6.13 \pm \\
0.38\end{array}$ & \\
\hline October & & $15.2 \pm 0.36$ & & $6.1 \pm 0.79$ & & $70.25 \pm 8.69$ & & $89.33 \pm 11$ & & $\begin{array}{c}5.61 \pm \\
0.23\end{array}$ & \\
\hline November & & $17.06 \pm 0.73$ & & $6.46 \pm 0.49$ & & $77.35 \pm 4.8$ & & $136.33 \pm 5.03$ & & $\begin{array}{c}4.67 \pm \\
0.04\end{array}$ & \\
\hline December & & $16.83 \pm 0.41$ & & $6.46 \pm 0.32$ & & $77.42 \pm 3.5$ & & $94.66 \pm 29.3$ & & $\begin{array}{c}5.76 \pm \\
0.47\end{array}$ & \\
\hline January & & $18.8 \pm 0.36$ & & $6.06 \pm 0.2$ & & $75.09 \pm 2.13$ & & $110.66 \pm 14.7$ & & $\begin{array}{c}5.12 \pm \\
0.28\end{array}$ & \\
\hline February & & $16.53 \pm 0.41$ & & $6.43 \pm 0.15$ & & $76.19 \pm 1.94$ & & $104.66 \pm 4.72$ & & $\begin{array}{c}5.74 \pm \\
0.04\end{array}$ & \\
\hline Mean & & $13.16 \pm 4.94$ & & $7.26 \pm 0.95$ & & $79.55 \pm 7.94$ & & $\begin{array}{c}100.08 \pm \\
18.79\end{array}$ & & $\begin{array}{c}5.55 \pm \\
0.41\end{array}$ & \\
\hline March & \multirow{12}{*}{ Capivari } & $20.53 \pm 0.2$ & & $5.5 \pm 0.2$ & & $69.6 \pm 2.29$ & & $61.33 \pm 3.05$ & & $\begin{array}{c}6.28 \pm \\
0.1\end{array}$ & \\
\hline April & & $18.16 \pm 0.83$ & & $8.13 \pm 0.25$ & & $99.47 \pm 1.65$ & & $89 \pm 7.81$ & & $\begin{array}{c}5.95 \pm \\
0.09\end{array}$ & \\
\hline May & & $13.23 \pm 0.25$ & & $7.86 \pm 0.15$ & & $86.04 \pm 2.12$ & & $88.33 \pm 15.5$ & & $\begin{array}{c}5.74 \pm \\
0.31 \\
\end{array}$ & \\
\hline June & & $8.36 \pm 0.92$ & & $8.36 \pm 1.2$ & & $80.99 \pm 11$ & & $96 \pm 8.18$ & & $\begin{array}{c}5.55 \pm \\
0.14\end{array}$ & \\
\hline July & & $8.96 \pm 0.92$ & & $8.33 \pm 0.15$ & & $82.66 \pm 1.67$ & & $55.66 \pm 9.29$ & & $\begin{array}{c}6.52 \pm \\
0.17\end{array}$ & \\
\hline August & & $9.96 \pm 0.55$ & & $8 \pm 0.4$ & & $81.19 \pm 3$ & & $51 \pm 5.56$ & & $\begin{array}{c}6.47 \pm \\
0.08\end{array}$ & \\
\hline September & & $15.26 \pm 0.2$ & & $7.56 \pm 0.4$ & & $86.51 \pm 4.28$ & & $87.66 \pm 7.37$ & & $\begin{array}{c}5.75 \pm \\
0.25\end{array}$ & \\
\hline October & & $12.7 \pm 1.53$ & & $8.13 \pm 0.45$ & & $88.69 \pm 4.73$ & & $57 \pm 4.35$ & & $\begin{array}{c}6.61 \pm \\
0.08\end{array}$ & \\
\hline November & & $19.56 \pm 0.77$ & & $6.13 \pm 0.58$ & & $76.97 \pm 6.21$ & & $52.66 \pm 12$ & & $\begin{array}{c}6.21 \pm \\
0.18\end{array}$ & \\
\hline December & & $21.13 \pm 0.11$ & & $6.26 \pm 0.75$ & & $81.03 \pm 9.7$ & & $49.66 \pm 8.08$ & & $\begin{array}{c}6.49 \pm \\
0.22 \\
\end{array}$ & \\
\hline January & & $20.96 \pm 0.11$ & & $6.8 \pm 0.98$ & & $\begin{array}{c}87.63 \pm \\
12.63\end{array}$ & & $64.66 \pm 1.52$ & & $\begin{array}{l}6.1 \pm \\
0.02\end{array}$ & \\
\hline February & & $20.03 \pm 1.1$ & & $6.66 \pm 0.11$ & & $84.48 \pm 2.12$ & & $69.66 \pm 0.57$ & & $\begin{array}{c}6.32 \pm \\
0.15\end{array}$ & \\
\hline Mean & & $15.74 \pm 4.93$ & & $7.31 \pm 0.99$ & & $83.77 \pm 7.19$ & & $68.56 \pm 17.09$ & & $\begin{array}{c}6.17 \pm \\
0.35\end{array}$ & \\
\hline
\end{tabular}

SD: standard deviation. 
(juveniles and adults). In the Capivari River, the sampling methods significantly affected the number of captured juveniles $(p=0.0036 \mathrm{df}=$ 8.01). On the other hand, in the Arraial River, the sampling method affected the number of adults sampled $(p=0.0021 \mathrm{df}=11.14)$.

The males' $\mathrm{CL}$ ranged between 3.66-22.55 mm in the Arraial River and between $3.51-33.50 \mathrm{~mm}$ in the Capivari River. For females, these values ranged between 3.61-20.77 $\mathrm{mm}$ in the Arraial River, and between 3.65-23.26 mm in the Capivari River. The mean $\mathrm{CL}$ of males and females in the Arraial River was of $14.29 \pm 2.91 \mathrm{~mm}$ and $13.03 \pm$ $2.45 \mathrm{~mm}$, while in the Capivari River these values were of $17.74 \pm 6.69 \mathrm{~mm}$ and $12.32 \pm 4.34 \mathrm{~mm}$, respectively. There was a statistically significant difference regarding the mean $\mathrm{CL}$ between males and females in each river, as well as in the comparison between the two locations $(p<0.05)$ (Table III).

In both rivers, the sex ratio was influenced by the sampling method. In the Arraial River, for the combined data the sex ratio was of 1.53 males/females, following the expected 1:1 (male:female) proportion only in the months of April, June, October, November, December and January ( $p>0.05)$ (Figure 2a). On the other hand, in the Capivari River the sex ratio was 1.92 males/ females, following the expected proportion only in the months of May and January ( $p>0.05)$ (Figure 3a).

When the sex ratio was analyzed using only data from the handnet captures, values of 1.12 and 1.03 males/females were obtained for the Arraial and Capivari rivers, respectively. In both these cases, the sex ratio fitted the expected 1:1 (males:females) proportions in all months (Figures $2 b$ and $3 b$ ).

Regarding only the data from traps, the sex ratio for the Capivari River was of 1.32 males/ females, following the expected 1:1 (male/ female) proportions in the months of April,

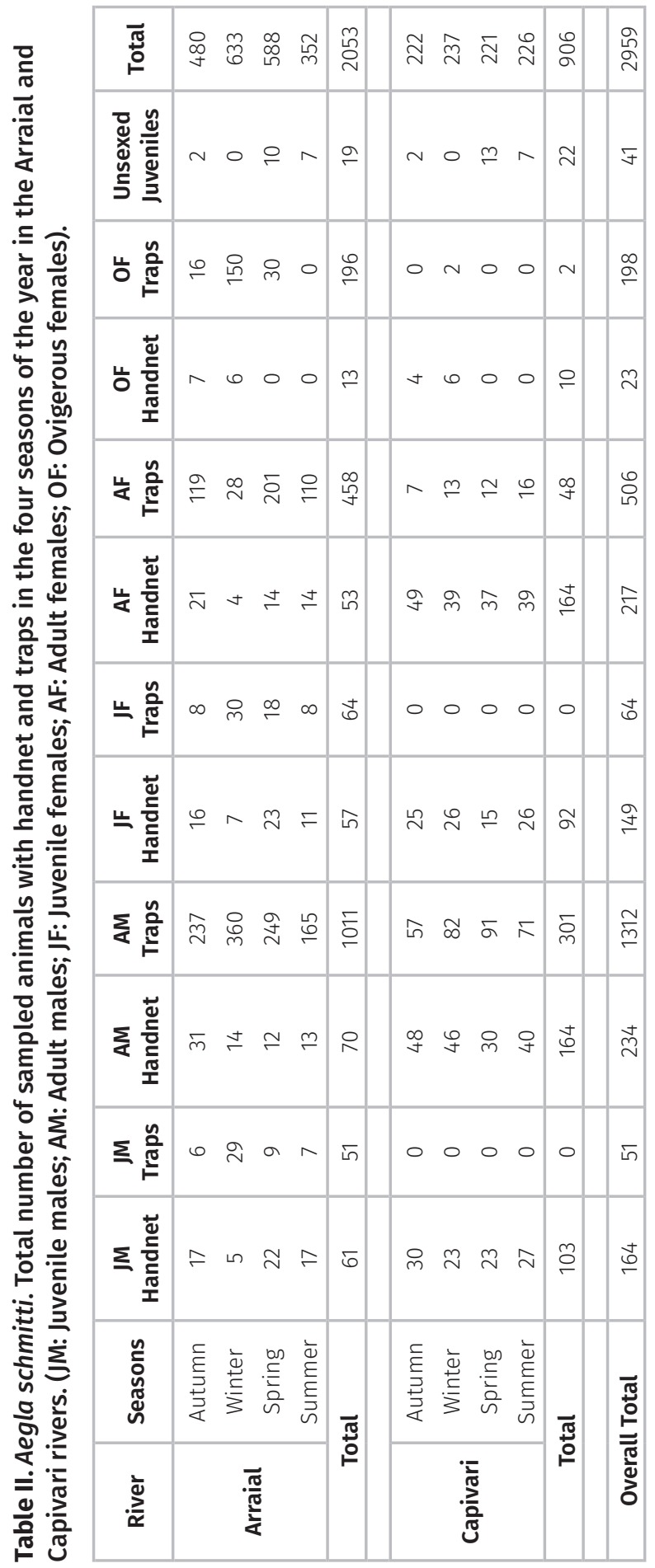


June, September, November and December. Contrastingly, for the Capivari River the sex ratio calculated using data from traps was of 5.57 males/females, and did not fit the expected 1:1 proportion in none of the months of the year (Figures $2 \mathrm{c}$ and $3 \mathrm{c}$ ).

The frequency distribution of the $\mathrm{CL}$ size classes reported different traits for the two populations sampled. In the Arraial River, the histogram was unimodal for both males and females, while in the Capivari River it was polymodal for both sexes (Figure 4).
The sex ratio within the $\mathrm{CL}$ classes was similar between the two rivers, with a predominance of males in the large size classes, and females in the intermediate and small classes (Fig. 4). The results of the Chi-squared test showed a significantly large proportion of males in all classes above class $16(15.01 \dashv 16 \mathrm{~mm})$ in the Arrail River and class $20(19.01 \dashv 20 \mathrm{~mm})$ in the Capivari River. The females in the Arraial River were most abundant from classes $9(8 \dashv 9 \mathrm{~mm})$ to 14 (13-1 $14 \mathrm{~mm}$ ) but exhibited significant differences only for the classes $11(10 \dashv 11 \mathrm{~mm})$ and $14(13 \dashv 14 \mathrm{~mm})(p<0.05)$. For the Capivari

Table III. Comparison of the values of the components of the von Bertalanffy growth equations in studied species of Aegla. Ca: mean maximum carapace length; k: growth rate; to: life time (in days) of the smallest specimen sampled; Lo: longevity.

\begin{tabular}{|c|c|c|c|c|c|c|c|c|c|}
\hline Species & Author, year & $\begin{array}{c}\text { Ca Males } \\
(\mathrm{mm})\end{array}$ & $\begin{array}{c}\mathrm{C} \alpha \\
\text { Females } \\
(\mathrm{mm})\end{array}$ & $\begin{array}{c}\mathbf{k} \\
\text { Males }\end{array}$ & $\begin{array}{c}\mathbf{k} \\
\text { Females }\end{array}$ & $\begin{array}{c}\text { to } \\
\text { Males }\end{array}$ & $\begin{array}{c}\text { to } \\
\text { Females }\end{array}$ & $\begin{array}{c}\text { Male } \\
\text { longevity } \\
\text { (years) }\end{array}$ & $\begin{array}{c}\text { Female } \\
\text { longevity } \\
\text { (years) }\end{array}$ \\
\hline A. platensis & $\begin{array}{c}\text { Bueno et al. } \\
(2000)\end{array}$ & 17.39 & 19.12 & 0.0041 & 0.0033 & 39.13 & 50.38 & $2.5^{\star}$ & - \\
\hline A. leptodactyla & $\begin{array}{c}\text { Noro \& } \\
\text { Buckup } \\
(2003)\end{array}$ & 19.83 & 18.96 & 0.0023 & 0.0024 & 55.5 & 48.6 & $2.5^{\star \star}$ & - \\
\hline A. jarai & $\begin{array}{c}\text { Boos Jr et al. } \\
\quad(2006)\end{array}$ & 25.11 & 23.56 & 0.0082 & 0.0048 & 29.02 & 46.45 & 2.0 & 2.0 \\
\hline A. longirostri & $\begin{array}{c}\text { Silva- } \\
\text { Castiglioni } \\
\text { et al. (2006) }\end{array}$ & 27.9 & 21.45 & 0.0069 & 0.0048 & 24.78 & 45.62 & 1.9 & 2.0 \\
\hline $\begin{array}{c}\text { A. } \\
\text { itacolomiensis }\end{array}$ & $\begin{array}{c}\text { Silva- } \\
\text { Gonçalves et } \\
\text { al. (2009) }\end{array}$ & 23.21 & 19.49 & 0.0094 & 0.0065 & 7.03 & 11.16 & 2.2 & 2.5 \\
\hline A. manuinflata & $\begin{array}{l}\text { Trevisan } \\
\text { \& Santos } \\
(2011)\end{array}$ & 28.00 & 25.16 & 0.0047 & 0.0051 & 10.63 & 17.65 & 3.0 & 2.5 \\
\hline A. schmitti & $\begin{array}{l}\text { Chiqueto- } \\
\text { Machado et } \\
\text { al. (2016) }\end{array}$ & 28.35 & 21.69 & 0.0019 & 0.002 & 33.6 & 44.04 & 2.84 & 3.2 \\
\hline $\begin{array}{l}\text { A. schmitti } \\
\text { (Arraial river) }\end{array}$ & $\begin{array}{l}\text { Current } \\
\text { study }\end{array}$ & 26.50 & 23.07 & 0.004 & 0.0027 & 23.18 & 53.36 & 2.5 & 2.0 \\
\hline $\begin{array}{c}\text { A. schmitti } \\
\text { (Capivari river) }\end{array}$ & $\begin{array}{l}\text { Current } \\
\text { study }\end{array}$ & 34.79 & 25.52 & 0.0024 & 0.0033 & 122.34 & 19.34 & 3.0 & 2.0 \\
\hline
\end{tabular}

* Longevity data available for males only.

** Due to the fact that the growth curve is underestimated, the authors cite that the animals take two and a half years to reach the carapace length of $18 \mathrm{~mm}$. 
River, even though females are more abundant than males only in class $9(8 \dashv 9 \mathrm{~mm})(p<0.05)$, they were numerically superior in classes 4 ( $3 \dashv$ $4 \mathrm{~mm}$ ) to 18 ( $17 \dashv 18 \mathrm{~mm})$ ( $p>0.05)$ (Fig. 4).

The frequency distribution in $\mathrm{CL}$ classes in the sampling months shows that juvenile individuals were sampled during all months of the year, without any statistically significant difference between the sampling months $(p>0.05)$ in both rivers (Figures S1 and S2 Supplementary Material). However, unsexed juveniles (classes 2 and 3) were found only during February-March and October-December in the Arraial River, and during March and OctoberJanuary in the Capivari River. These months correspond to the austral spring and summer, seasons that come following the main spawning season of $A$. schmitti, which occurs from April to October in the Arraial River and from April to August in the Capivari River. The following demographic categories were found in all the sampling months, for which the histograms were polymodal in both rivers (Fig. 5).

For both populations sampled, it is possible to evaluate a cohort of sexually undifferentiated juveniles, with a highest number in October and occurring until March. For the other CL size classes, clearly distinguished age cohorts could not be identified, with cohorts of individuals of intermediate and large size classes alternating along the months of the year.

Another inference concerning a possible recruitment peak during spring are the modes observed in the histograms, where in both locations the frequency peaks of individuals belonging to the smallest size classes (1 o 6) were observed in October, November and December, probably originating from the spawning which occurred after the end of the mating seasons of both populations.

The histograms of $\mathrm{CL}$ size classes indicated that animals belonging to the smallest classes,
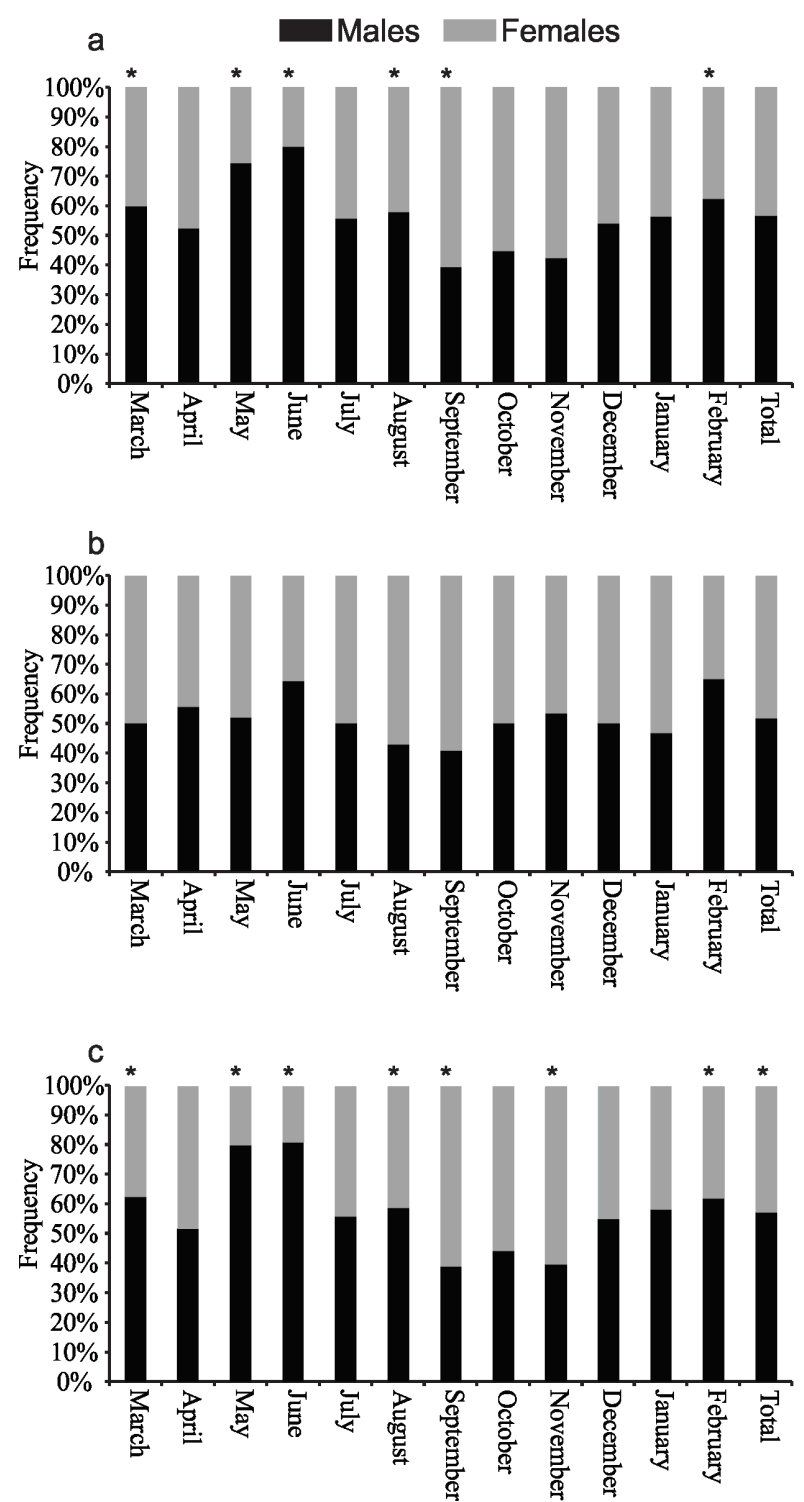

Figure 2. Aegla schmitti: Sex ratio in the Arraial River. a: Combined data. b: Animals sampled with handnets. c: Animals sampled with traps. ${ }^{*}=$ significant difference according to the Chi-squared test.

in both rivers, have abundance peaks in October. Thus, we chose to monitor the animals' growth from this month onwards, and consider these aeglids as the first cohort in the study of modal displacement, being placed ahead of the group of large animals that were sampled in the previous period. This procedure was based in Noro \& Buckup (2003), Silva-Castiglioni et al. (2006) and Trevisan \& Santos (2011), which demonstrated 
that this approach fits the our data, given that the growth pattern of aeglid populations do not exhibit significant changes between years.

In the Arraial River, the growth curves for males and females corresponded to the following equations, respectively: $\mathrm{Ct}=26.50[1-\mathrm{e}$ ${ }^{-0.004(t+53.36)}$ ] and $C t=23.07\left[1-^{-}-0.0027(t+23.18)\right]$ (Figure 5a and b). For the Capivari River, the growth curve for males was of $\mathrm{Ct}=34.79\left[1-\mathrm{e}^{-0.0024(\mathrm{t}+122.34)}\right]$, while
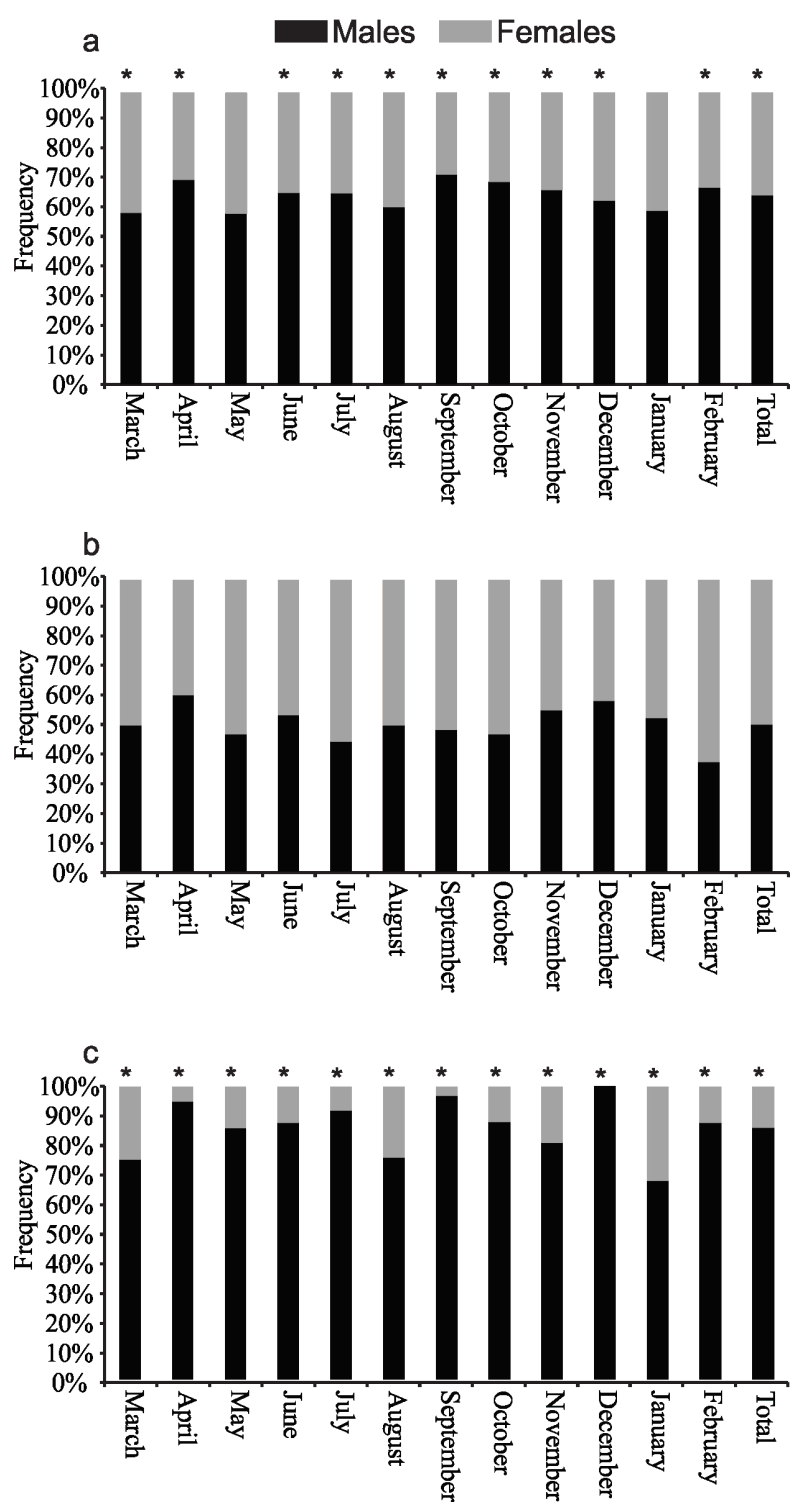

Figure 3. Aegla schmitti: Sex ratio in the Capivari River. a: Combined data. b: Animals sampled with handnets. c: Animals sampled with traps. ${ }^{*}=$ significant difference according to the Chi-squared test. for females it was of $\mathrm{C} t=25.52\left[1-\mathrm{e}^{-0.0033(\mathrm{t}+19.51)}\right]$ (Figure $5 c$ and $d$ ).

In both sampling sites, the maximum $\mathrm{CL}$ estimated by the von Bertalanffy model were closely matched to the size of the largest males and females captured, with values of 26.50 and $34.79 \mathrm{~mm} \mathrm{CL}$ for the males, and 23.07 and 25.52 $\mathrm{mm} \mathrm{CL}$ for the females of the Arraial and Capivari rivers, respectively (Table III).

Different growth rates between the sexes of both sampling sites were observed. While in the Arraial River the males had higher growth rates than females, the opposite was reported for the Capivari River, where females exhibit higher growth rates than males. When individuals of the same sex were compared between the rivers, growth rates were similar for females (0.0027 and 0.0033 for the Arraial and Capivari rivers), but dissimilar between males (0.004 for the Arraial River, and 0.0024 for the Capivari River).

Longevity was estimated in approximately 2.5 years for males of the Arraial River, 3 years for males of the Capivari River, and 2 years for females of both populations. After the linearization of the growth curves and comparisons of their slopes and intercepts, it was possible to observe statistically significant differences between the sexes and between the sampling sites, indicating a differential growth pattern for each group $(p<0.05)$.

\section{DISCUSSION}

The selectivity regarding the sex and size of captured animals with each sampling technique (hand net and traps) observed in this study can be associated with the different behavioral patterns of the populations of A. schmitti. More specifically, this result could be a consequence of the $\mathrm{CL}$ size patterns, in which males were similar in size to females in one location (Arraial River), 
but larger than females in another (Capivari River). Considering that in the Capivari River the adult males are much larger than individuals belonging to other demographic categories, the smaller females and juveniles may not have entered the traps to avoid confrontations with these large males. On the other hand, females of the Arraial River were closely matched in size to the males, which could mitigate this effect and explain the high capture rate of females in this river. In Aegla the combination of cephalothorax length and claw height differences between individuals are decisive to avoid agonistic behavior as well as to the contest outcome. In general, the increase of size differences between opponents decreases the probability of contest and increase an avoidance response by the smaller individual, which seems to be the case of the study (Hardy \& Briffa 2013, Palaoro et al. 2014). Given that the selectivity of the sampling methods mentioned above was a consequence of the distinct behavioral pattern of two populations, subjected to different environmental characteristics, future studies that employ only one of these capture methods should explore their results with caution.
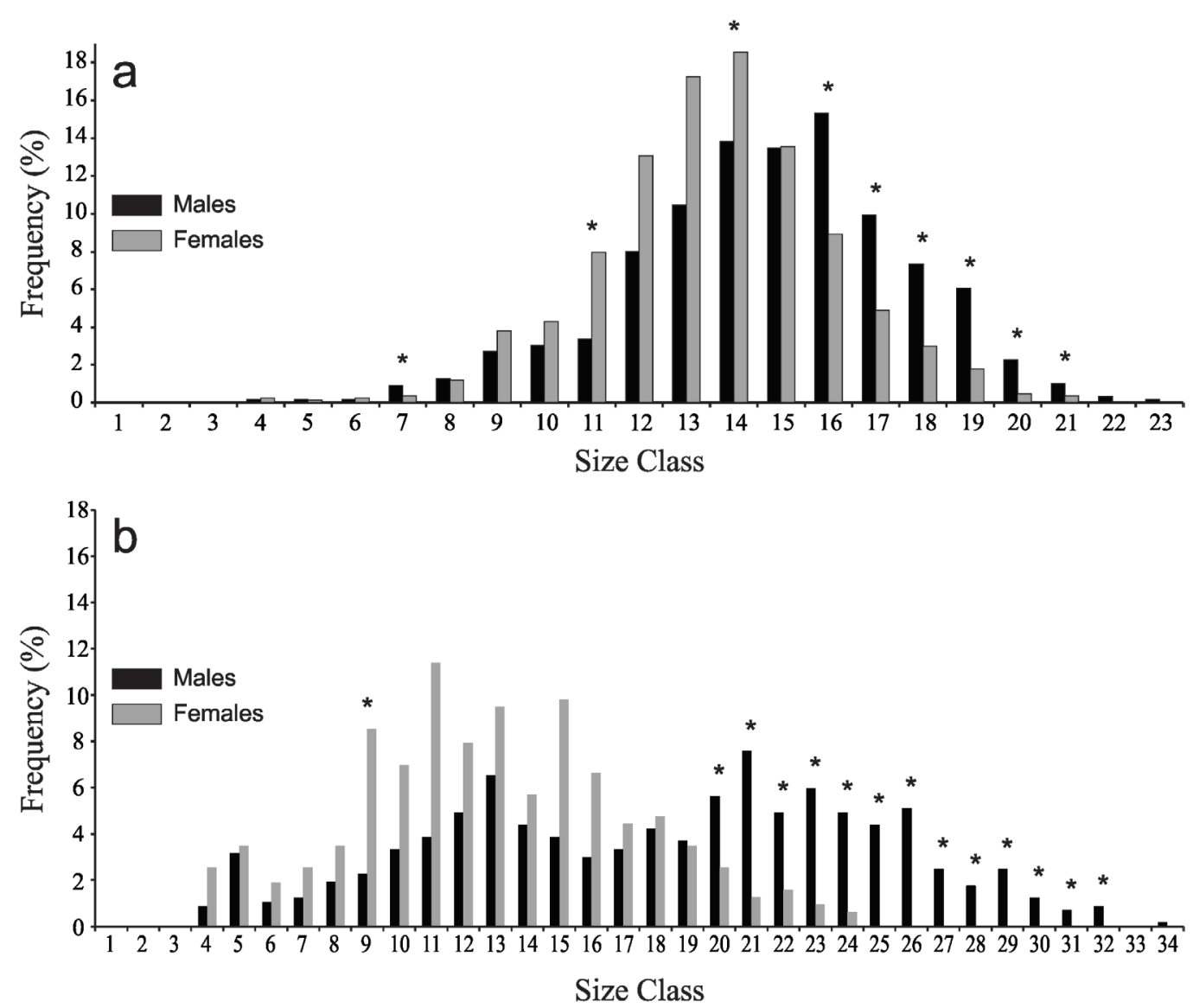

Figure 4. Aegla schmitti. Frequency distributions regarding the carapace of males and females and sex ratio in the size classes of the Arraial (a) and Capivari (b) rivers. The symbol * indicates statistically significant difference in the sex ratio. Size classes (mm): (1) $0 \nmid 1$; (2) $1.01 \dashv 2$; (3) $2.01 \dashv 3$; (4) $3.01 \dashv 4$; (5) $4.01 \dashv 5$; (6) $5.01 \dashv 6$; (7) $6.01 \dashv 7$; (8) $7.01 \dashv 8$; (9) $8.01 \dashv 9 ;(10) 9.01 \dashv 10 ;(11) 10.01 \dashv 11$; (12) $11.01 \dashv 12 ;(13) 12.01 \dashv 13 ;(14) 13.01 \dashv 14 ;(15) 14.01 \dashv 15 ;$ (16) $15.01 \dashv 16$; (17) $16.01 \dashv 17$; (18) $17.01 \dashv 18$; (19) $18.01 \dashv 19 ;$ (20) $19.01 \dashv 20$; (21) $20.01 \dashv 21$; (22) $21.01 \dashv 22$; (23) 22.01 $\dashv 23 ;(24) 23.01 \dashv 24 ;(25) 24.01 \dashv 25 ;$ (26) $25.01 \dashv 26$; (27) $26.01 \dashv 27$; (28) $27.01 \dashv 28$; (29) $28.01 \dashv 29$; (30) $29.01 \dashv 30$; (31) $30.01 \dashv 31 ;(32) 31.01 \dashv 32 ;(33) 32.01 \dashv 33 ;(34) 33.01 \dashv 34$. 
The larger size of males when compared to females is also reported for other nine aeglids species for which morphometric analyses were performed (Lopez 1965, Rodrigues \& Hebling 1978, Swiech-Ayoub \& Masunari 2001b, Noro \& Buckup 2003, Colpo et al. 2005, Gonçalves et al. 2006, Teodósio \& Masunari 2009, Cohen et al. 2011, Trevisan \& Santos 2012). The larger size of the males can be explained by the necessity of females to allocate energy for the production and incubation of nutrient-rich eggs, a period during which females of some species cannot feed. On the other hand, males could allocate most of their energy for somatic growth, a fact that leads directly to them exhibiting larger body sizes than females. For Aegla platensis Schmitti, 1942, A. castro and Aegla marginata BondBuckup \& Buckup, 1994, (Bueno et al. 2000), which represent the exceptions to this rule (females larger than males), behavioral factors such as migrations, different responses to environmental variations and/or disturbances, and differential exploration of resources and microhabitats could explain the size difference between the sexes (Passano 1960, Hartnoll 1982). This explanation can also be applied to the conspicuous size difference between individuals of each sex that was observed in the Capivari River.

The sex ratio is one of the main traits of a given population, regulating the number of individuals and the population's reproductive potential. Thus, in natural populations, the sex ratio tends to remain close to 1:1 due to the action of natural selection (Fisher 1930, Giesel 1972). However, the sex ratio reported in this study followed the abnormal pattern described by Wenner (1972), with females dominating in
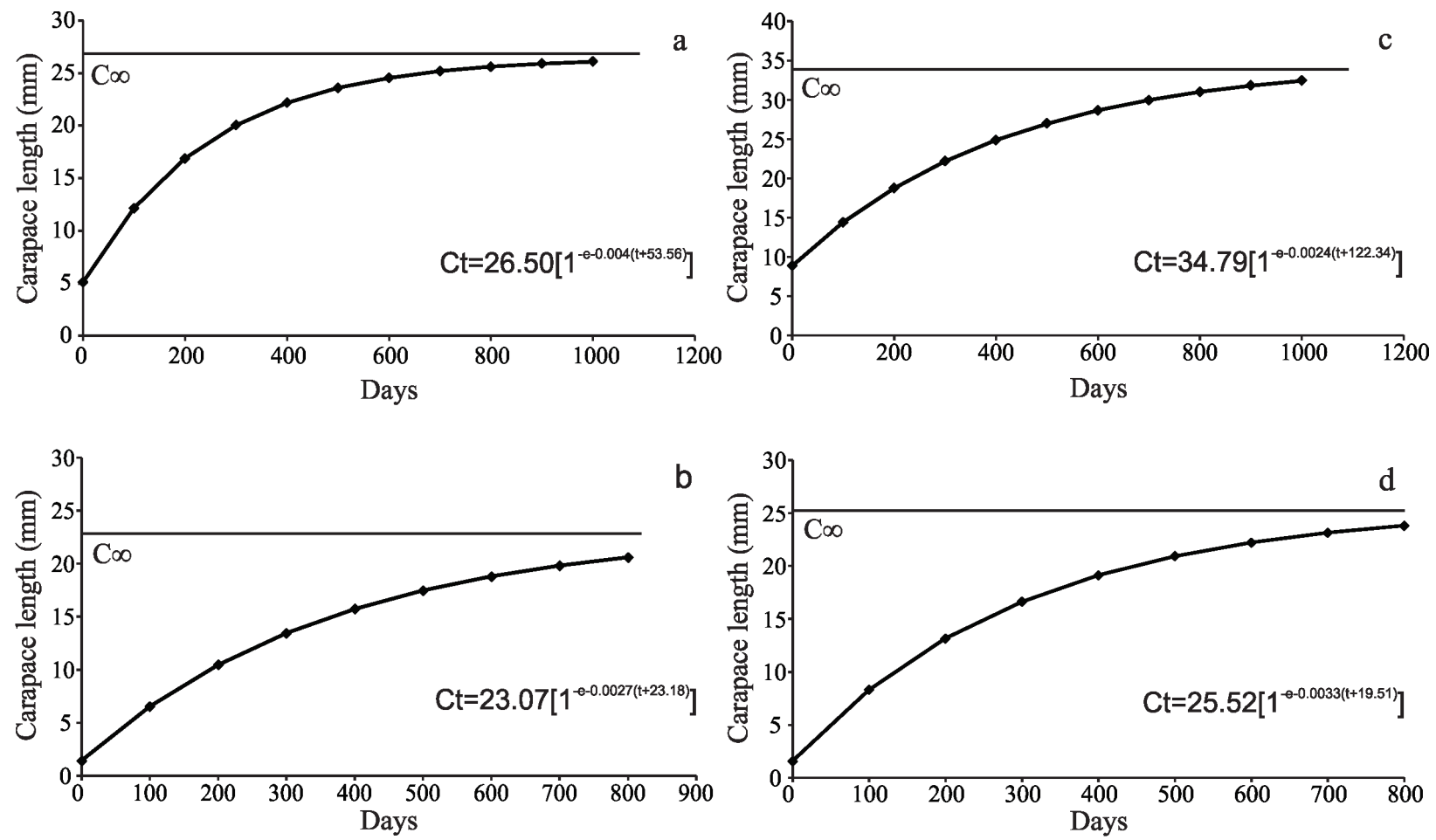

Figure 5. Aegla schmitti in the Arraial River ( $a$ and b) and Capivari River (c and d). Growth curves for males (a and c) and females ( $b$ and $d$ ) based on the von Bertalanffy (1938) model. (Ct) carapace length in a given t time; (C $\alpha$ ) mean maximum carapace length $(\mathrm{mm}) ;(\mathrm{t})$ age, in days. 
the intermediary $\mathrm{CL}$ size classes, and males dominating the large $\mathrm{CL}$ size classes. This pattern was also reported to other aeglids such as A. castro, A. fransiscana and A. manuinflata (Swiech-Ayoub \& Masunari 2001a, Gonçalves et al. 2006, Trevisan \& Santos 2011). The presence of this pattern may be attributed to the differential growth of individuals of each sex, especially after the puberty molt: males have higher growth rates than females. Thus, males tend to predominate in the large $\mathrm{CL}$ classes, while females predominate in the intermediary ones (Passano 1960, Hartnoll 1982, Colpo et al. 2005, Cohen et al. 2011, Trevisan \& Santos 2011).

In the Arraial river the population showed a unimodality of the $C L$ frequency distribution histogram while Capivari population polymodality. This difference demonstrates distinct types of stability in these populations, due biotic interaction or an indirect consequence of environmental factors. Migration, recruitment pulses, mortality or behavior might explain the unimodaly or bimodality pattern (Díaz \& Conde 1989). The Arraial population belongs to a hydrographic basin that is restricted to the easternmost portion of the Parana state, geographically isolated by the Serra do Mar mountain range, being thus less likely to be affected by migration (Trevisan et al. 2016). Likewise, the similarity regarding the size composition of the sexes may have attenuated the effects of behavioral differences, such as sex-specific mortality rates. On the other hand, in Capivari the population was smaller and fragmented, and its CL frequency distribution histogram was polymodal, a possible indicator of stress and prevention of a full development situation. The low percentage of ovigerous females sampled in this site corroborates this inference (5.36\% of adult females were ovigerous, against $29.02 \%$ in the Arraial River). Another factor that may have contributed to this pattern is the presence of pool regions, alternated with riffles, may have interfered in the sampling process. The presence of these pool regions is likely associated with a reduced protection of the water body by riparian forest, which optimizes the leaching of dry land sediments into the water column (Trevisan 2013).

The higher mean water temperature in Capivari river might also contributed for the polymodality CL frequency of distribution histogram. Decapods show reduce metabolism and behavior changes when facing thermal stress, as temperature increase (Lagerspetz \& Vainio 2006, Cerezer 2017). The Capivari population showed a lower growth rate, as consequence reaching higher longevity and larger sizes. This longer longevity allied with migrations, recruitment pulses, mortality or behavioral changes could alter CL frequency on the population. Future studies evaluating the effect of temperature increase on population structure should carry out to elucidate this question.

However, the low frequency of ovigerous females is interpreted as a consequence behavior associated to them, such as burying themselves in the sediment and preferring to inhabit the marginal areas of the stream, which may difficult their sampling (Bahamonde \& Lopez 1961, Lopez 1965, Bueno \& Bond-Buckup 2000, Teodósio \& Masunari 2009), a fact that may have occurred in the Capivari River.

In this study, even though juveniles occur in similar numbers along the seasons of the year, the occurrence of small-sized juveniles from October to December indicates that the two populations produce their first cohort in the months that follow the spawning period. Similarly, to the reproductive period in Aelidae (see revision in Bueno \& Shimizu 2009), the recruitment period may vary according to the region, ranging from a few months in species 
such as A. longirostri (Colpo et al. 2005), A. platensis (Bueno \& Bond-Buckup 2000), A. castro (Swiech-Ayoub \& Masunari 2001a, Fransozo et al. 2003), and A. franciscana (Gonçalves et al. 2006), to continuous (the entire year) as in $A$. manuinflata (Trevisan \& Santos 2011).

Regarding the parameters obtained with the von Bertalanffy (1938) model, it was possible to observe that the values of asymptotic growth were different between the sexes of $A$. schmitti in both rivers sampled, confirming the previous records from other authors $A$. leptodactyla, A. longirostri, A. jarai, A. itacolomiensis and A. manuinflata (Noro \& Buckup 2003, SilvaCastiglioni et al. 2006, Boos Jr et al. 2006, SilvaGonçalves et al. 2009, Trevisan \& Santos 2011, respectively).

The intra- and interspecific comparison between the growth curves, growth rates, maximum size and longevity of aeglids shows distinct patterns, regardless of the sampling site or the relationship between the sexes (Table II). Similar growth rates between the sexes, such as those observed in the Capivari River, are also reported for other species of Aeglidae. However, the opposite pattern is also observed among distinct populations and species of the same family. The same variation pattern, including cases of both similarity and dissimilarity, is observed for longevity and growth curves (Bueno et al. 2000, Noro \& Buckup 2003, Boos Jr et al.2006, Silva-Castiglioni et al. 2006, Silva-Gonçalves et al. 2009, Trevisan \& Santos 2011). This fact might be associated with different mortality rates arising from biological interactions, differential mortality rates between the sexes, availability of food resources, migrations and capacity to endure environmental stresses, spatio-temporal imbalances in the use of food resources, and different behavioral patterns (Giesel 1972, Wolf et al. 1975, Montague 1980).
The present study demonstrated the selectivity regarding the size and life stage of individuals related to the sampling techniques used for aeglids. Besides, it was possible to estimate the longevity, growth rate, maximum size and structure of two populations of $A$. schmitti belonging to different hydrographic basins. Thus, the data obtained allowed for the characterization of the growth of $A$. schmitti, providing useful information for this species' conservation.

\section{Acknowledgments}

The authors are grateful to the Programa de PósGraduação em Zoologia and the researchers of the Laboratory of Ecology of Crustacea of the Universidade Federal do Paraná for the infrastructure provided and for the support during the development of this study; and to the Conselho Nacional de Desenvolvimento Científico e Tecnológico (CNPq) for the research grant provided for the second author (process no. 141212/20136). All biological samples collected for the present study complied with the current laws of the Brazilian Federal Government and were conducted with the permission of the "Brazilian Institute of Environment and Renewable Natural Resources" (IBAMA) (Authorization \#16140-1 DIFAP/ IBAMA, 17/071998).

\section{REFERENCES}

ALLEN RL. 1976. Method for comparing fish growth curves. New Zeal J Mar Fresh 10(4): 687-692.

ARENAS RL. 1976. La cordillera de la costa como refugio de la fauna dulcícola preglacial. Archivos de Biología y Medicina Experimentales, Santiago, 40 p.

AYRES M, AYRES JR M, AYRES DL \& SANTOS AAS. 2007. Bioestat 5.0 aplicações estatísticas nas áreas das ciências biológicas e médicas. Belém: IDSM, 364 p.

BAHAMONDE N \& LOPEZ MT. 1961. Estudios biologicos en la populacion de Aegla laevis laevis (Latreille) de el Monte (Crustacea, Decapoda, Anomura). Investnes Zool Chil 7: 19-58.

BAPTISTA C, PINHEIRO MAA, BLANKENSTEYN A \& BORZONE CA. 2003. Estrutura populacional de Callinectes ornatus Ordway (Crustacea, Portunidae) no Balneário de 
Shangri-Lá, Pontal do Paraná, Paraná, Brasil. Rev Bras Zool 20(4): 661-666.

BARTHOLOMEI-SANTOS ML, RORATTO PA \& SANTOS S. 2011. High genetic differentiation of Aegla longirostri (Crustacea, Decapoda, Anomura) populations in southern Brazil revealed by multi-loci microsatellite analysis. Genet Mol Res 10: 4133-4146.

BIGARELLA JJ. 1978. A Serra do Mar e a porção ocidental do Estado do Paraná. Governo do Paraná, Secretaria de Estado do Planejamento e Associação de defesa e Educação Ambiental, Curitiba, 248 p.

BOND-BUCKUP G \& BUCKUP L. 1994. A familia Aeglidae (Crustacea, Decapoda, Anomura). Arch Zool Est São Paulo 2: 159-346.

BOOS JR H, SILVA-CASTIGLIONI DD, SCHACHT K, BUCKUP L \& BOND-BUCKUP G. 2006. Growth of Aegla jarai BondBuckup \& Buckup (crustacea, anomura, aeglidae). Rev Bras Zool 23(2): 490-496.

BRANCO LO \& FRACASSO HAA. 2004. Biologia populacional de Callinectes ornatus (Ordway) na Armação do Itapocoroy, Penha, Santa Catarina, Brasil. Rev Bras Zool 21(1): 91-96.

BUCKUP L \& ROSSI A. 1979. O gênero Aegla no Brasil (Crustacea, Decapoda, Anomura, Aeglidae). Rev Bras Zool 37(4): 879-892.

BUENO AAP \& BOND-BUCKUP G. 2000. Dinâmica populacional de Aegla platensis Schmitt (Crustacea, Decapoda, Aeglidae). Rev Bras Zool 17(1): 43-49.

BUENO AAP \& BOND-BUCKUP G. 2004. Natural Diet of Aegla platensis and Aegla lingulata Bond-Buckup \& Buckup (Crustacea, Decapoda, Aeglidae) from Brazil. Acta Limnol Bras 16(2): 115-127.

BUENO AAP, BOND-BUCKUP G \& BUCKUP L. 2000. Crescimento de Aegla platensis em ambiente natural (Crustacea, Decapoda, Aeglidae). Rev Bras Zool 17(1): 43-49.

BUENO SLS \& SHIMIZU RM. 2009. Allometric growth, sexual maturity, and adult male chelae dimorphism in Aegla franca (Decapoda: Anomura: Aeglidae). J Crustacean Biol 29(3): 317-328.

BUENO SLS, SHIMIZU RM \& ROCHA SS. 2007. Estimating the population size of Aegla franca (Decapoda: Anomura: Aeglidae) by mark-recapture technique from an isolated section of Barro Preto stream, county of Claraval, State of Minas Gerais, southeastern Brazil. J Crustacean Biol 27(4): 553-559.

BURNS JW. 1972. The distribution and life history of South American freshwater crabs (Aegla) and their role in trout streams and lakes. Trans Am Fish Soc 101(4): 595-607.
CEREZER C. 2017. Estresse oxidativo em Aegla longirostri (Decapoda, Anomura): efeito da temperatura e qualidade da água. Ph.D. Dissertation, Universidade Federal de Santa Maria, Santa Maria, 77 p.

CHIQUETTO-MACHADO PI, VIEIRA LC, SHIMIZU RM \& BUENO SL. 2016. Life Cycle of the Freshwater Anomuran Aegla Schmitti (Decapoda: Anomura: Aeglidae) From southeastern Brazil. J Crustacean Biol 36(1): 39-45.

COHEN FPA, TAKANO BF, SHIMIZU RM \& BUENO SLS. 2011. Life cycle and population structure of Aegla paulensis (Decapoda: Anomura: Aeglidae). J Crustacean Biol 31(3): 389-395.

COLPO KD, RIBEIRO LD \& SANTOS S. 2005. Population biology of the freshwater Anomura Aegla longirostri (Aeglidae) from South Braziliam streams. J Crustacean Biol 25(3): 495-499.

DÍAZ H \& CONDE JE. 1989. Population dynamics and life of mangrove crab Aratus pisonii (Brachyura, Grapsidae) in a marine environment. B Mar Sci 45(1): 148-163.

FISHER RA. 1930. The genetic theory of natural selection. Dover, $2^{\text {nd }}$ ed., 291 p.

FRANSOZO A, COSTA RC, REIGADA ALD \& NAKAGAKI JM. 2003. Population structure of Aegla castro Schmitt, 1942 (Crustacea: Anomura: Aeglidae) from Itatinga (SP), Brazil. Acta Limnol Bras 15(2): 13-20.

GIESEL JT. 1972. Sex ratio, rate of evolution, and environmental heterogeneity. Am Nat 106: 380-387.

GONÇALVES RS, CASTIGLIONI DS \& BOND-BUCKUP G. 2006. Ecologia populacional de Aegla franciscana (Crustacea, Decapoda, Anomura) em São Francisco de Paula, RS, Brasil. Iheringia 96(1): 109-114.

HARDY ICW \& BRIFFA M. 2013. Animal contests. Cambridge, U.K.: Cambridge University Press, 357 p.

HARTNOLL RG. 1982. Growth. In: Bliss DE (Ed), The Biology of Crustacea, Embriology, Morphology and Genetics, New York: Academic Press, p. 111-196.

JARA CG, PÉREZ-LOSADA M \& CRANDALL KA. 2018. Aegla chilota, new species of anomuran freshwater crab from Chiloé Island, western Patagonia. Nauplius 26: e2018029.

LAGERSPETZ KY \& VAINIO LA. 2006. Thermal behaviour of crustaceans. Biol Rev 81(2): 237-258.

LOPEZ MT. 1965. Estudios biologicos en Aegla odebrechtii paulensis, Schmitt (Crustacea, Decapoda, Anomura). Bol Zool Fac Fil Cien Letras 25: 301-315. 
LOPRETTO EC. 1978a. Estrutura exoesqueletaria y miologia del quinto par de pereiopodos del macho de la familia Aeglidae (Crustacea, Anomura). Limnobios 1(8): 284-198.

LOPRETTO EC. 1978b. Las especies de Aegla del centrooeste Argentinoen base a la morfologia comparada del quinto par de pareiopodos (Crustacea, Anomura, Aeglidae). Neotropica 24(71): 57-68.

LOPRETTO EC. 1979. Estúdio comparativo del quinto par de pereiopodos en los representantes de Aegla de la Patagonia Argentina (Crustacea, Anomura). Neotropica 25(73): 9-22.

LOPRETTO EC. 1980a. Analisis de las caracteristicas del quinto pereiopodo en las especies de Aegla del grupo "platensis" (Crustacea, Anomura, Aeglidae). Physis 39(96): 37-56.

LOPRETTO EC. 1980b. Clave para la determinación de las especies del genero Aegla de la Republica Argentina en base al estudio comparativo del quinto par de pereiopodos masculinos (Crustacea, Anomura, Aeglidae). Limnobios 1(10): 431-436.

MAACK R. 1981. Geografia física do Estado do Paraná. Paraná: J Olympio, 450 p.

MACDONALD PDM. 1987. The analisys of length-frequency distributions. In: Summerfelt RC and Hall G (Eds). Age and growth of fish, Ames, Iowa State University Press, USA, p. 371-384.

MACDONALD PDM \& PITCHER J. 1979. Age-groups from sizefrequency data: a versalite and efficient method of analyzing distribution mixtures. J Fish Res Board Can 36: 987-1001.

MAGNI ST \& PY-DANIEL V. 1989. Aegla platensis Schmitt, 1942 (Decapoda, Anomura) um predador de imaturos de Simuliidae (Diptera, Culicomorpha). Rev Saude Publ 23: 258-259.

MARÇAL IC, IOSHIMURA LM, ROSA JJDS \& TEIXEIRA GM. 2018. Population structure and sexual maturity of Aegla castro (Decapoda, Anomura), an endemic freshwater crab from Brazil. Invertebr Reprod Dev 62(1): 35-42.

MARGALEF R. 1983. Ecologia. Editora Omega, 951 p.

MARKUS R. 1971. Elementos de estatística aplicada da Faculdade de Agronomia e Veterinária da UFRGS, Centro Acadêmico Leopoldo Cortez, Porto Alegre, 329 p.

MARTINELLI LA \& KRUSCHE AV. 2004. Amostragem em rios. In: Bicudo CEM and Bicudo DC (Eds). Amostragem em Limnologia. São Carlos: RIMa, p. 263-279.

MASUNARI S. 2006. Distribuição e abundância dos caranguejos Uca Leach (Crustacea, Decapoda,
Ocypodidae) na Baía de Guaratuba, Paraná, Brasil. Rev Bras Zool 23(4): 901-914.

MONTAGUE CL. 1980. A natural history of temperate Western Atlantic fiddler crabs (Genus Uca) with reference to their impact on the salt marsh. Contrib Mar Sci 23: 25-55.

NORO CK \& BUCKUP L. 2002. Biologia reprodutiva e ecologia de Aegla leptodactyla Buckup \& Rossi, 1977 (Crustacea, Anomura, Aeglidae). Rev Bras Zool 19(4): 1063-1074.

NORO CK \& BUCKUP L. 2003. O crescimento de Aegla leptodactyla Buckup \& Rossi (Crustacea, Anomura, Aeglidae). Rev Bras Zool 20(2): 191-198.

PAEZ FP, MARCAL IC, SOUZA-SHIBATTA L, GREGATI RA, SOFIA SH \& TEIXEIRA GM. 2018. A new species of Aegla Leach, 1820 (Crustacea, Anomura) from the Iguaçu River basin, Brazil. Zootaxa 4527(3): 335-346.

PALAORO AV, DALOSTO MM, COSTA JR \& SANTOS S. 2014. Freshwater decapod (Aegla longirostri) uses a mixed assessment strategy to resolve contests. Anim Behav 95: 71-79.

PASSANO LM. 1960. Molting and its control. In: Talbot HW (Ed). The Physiology of Crustacea: metabolim and growth, Academic Press, New York, p. 473-536.

RINGUELET RA. 1949. Consideraciones sobre las relaciones filogenéticos entre las espécies del gênero Aegla Leach. Notas Mus 14: 11-118.

RODRIGUES W \& HEBLING NJ. 1978. Estudos biológicos em Aegla perobae Hebling e Rodrigues, 1977 (Decapoda, Anomura). Rev Bras Zool 38(2): 383-390.

SANTOS S, AYRES-PERES L, CARDOSO RCF \& SOKOLOWICZ CC. 2008. Natural diet of the freshwater anomuran Aegla longirostri (Crustacea, Anomura, Aeglidae). J Nat Hist 42(13-14): 1027-1037.

SANTOS S, BOND-BUCKUP G, GONÇALVES AS, BARTHOLOMEISANTOS ML, BUCKUP L \& JARA CG. 2017. Diversity and conservation status of Aegla spp. (Anomura, Aeglidae): an update. Nauplius 25: e2017011.

SILVA-CASTIGLIONI D, BARCELOS DF \& SANTOS S. 2006. O crescimento de Aegla longirostri Bond-Buckup \& Buckup (Crustacea, Anomura, Aeglidae). Rev Bras Zool 23(2): 408-413.

SILVA-GONÇALVES R, BOND-BUCKUP G \& BUCKUP L. 2009. Crescimento de Aegla itacolomiensis (Crustacea, Decapoda) em um arroio da Mata Atlântica no sul do Brasil. Iheringia 99(4): 397-402.

SNEDECOR GW \& COCHRAN WG. 1967. Statistical Methods. Ames, lowa State University, Press, 593 p. 
SPIEGEL MR. 1979. Estatística. McGraw-Hill do Brasil, São Paulo, 580 p.

SWIECH-AYOUB BP \& MASUNARI S. 2001a. Biologia reprodutiva de Aegla castro Schmitt (Crustacea, Anomura, Aeglidae) no Buraco do Padre, Ponta Grossa, Paraná, Brasil. Rev Bras Zool 18(3): 1019-1030.

SWIECH-AYOUB BP \& MASUNARI S. 2001b. Flutuações temporal e espacial de abundância e composição de tamanho de Aegla castro Schmitt (Crustacea, Anomura, Aeglidae) no Buraco do Padre, Ponta Grossa, Paraná, Brasil. Rev Bras Zool 18(3): 1003-1017.

TEODÓSIO EAO \& MASUNARI S. 2009. Estrutura populacional de Aegla schmitti (Crustacea: Anomura: Aeglidae) nos reservatórios dos Mananciais da Serra, Piraquara, Paraná, Brasil. Rev Bras Zool 26(1): 19-24.

TREVISAN A. 2013. Influência da Serra do Mar na distribuição e biologia de Aeglidae (Crustacea, Anomura) na porção leste do Estado do Paraná. Ph.D. Dissertation, Universidade Federal do Paraná, Curitiba, 258 p.

TREVISAN A, MAROCHI MZ, COSTA M, SANTOS S \& MASUNARI S. 2016. Effects of the evolution of the Serra do Mar mountains on the shape of the geographically isolated populations of Aegla schmitti Hobbs III, 1979 (Decapoda: Anomura). Acta Zool-Stockholm 97(1): 34-41.

TREVISAN A \& SANTOS S. 2011. Crescimento de Aegla manuinflata (Decapoda, Anomura, Aeglidae) em ambiente natural. Iheringia 101(4): 336-342.

TREVISAN A \& SANTOS S. 2012. Population dynamics of Aegla manuinflata (Anomura) in a stream of southern Brazil. Acta Limnol Bras 26(2): 154-162.

VON BERTALANFFY L. 1938. A quantitative theory of organic growth. Hum Biol 10(2): 181-213.

WENNER AM. 1972. Sex-ratio as a function of size in marine Crustacea. Am Nat 106: 321-350.

WOLF P, SHANHOLTAER SF \& REIMOLD RJ. 1975. Population estimates for Uca pugnax on Duplin estuary marsh, Geórgia, USA. Crustaceana 29: 79-91.

ZAR JH. 1996. Biostatistical analysis. New Jersey, PrenticeHall, 662 p.

ZIMMERMANN BL, MACHADO JVDV, SANTOS S \& BARTHOLOMEISANTOS ML. 2019. Genetic diversity of three Aegla species (Decapoda, Anomura) revealed by AFLP and mtDNA markers. Crustaceana 92(4): 445-462.

\section{SUPPLEMENTARY MATERIAL}

\section{Figures S1 and S2.}

\section{How to cite}

TREVISAN A, MAROCHI MZ \& MASUNARI S. 2021. Population structure and growth of two populations of Aegla Schmitti Hobbs III, 1979 (Anomura, Aeglidae) in the eastern Paraná state, Brazil. An Acad Bras Cienc 93: e20190750. DOI. 10.1590/0001-3765202120190750.

Manuscript received on July 3, 2019;

accepted for publication on September 19, 2019

\section{ANDRÉ TREVISAN ${ }^{1}$}

https://orcid.org/0000-0002-5897-2828

\section{MURILO Z. MAROCHI}

https://orcid.org/0000-0002-8994-8935

\section{SETUKO MASUNARI ${ }^{3}$}

https://orcid.org/0000-0001-8464-2323

${ }^{1}$ Universidade Alto Vale do Rio Peixe, Rua Victor Baptista Adami, 800, Caçador, 89500-000 Santa Catarina, SC, Brazil ${ }^{2}$ Universidade Estadual Paulista Júlio de Mesquita Filho, Instituto de Biociências, Praça Infante Dom Henrique, s/n, São Vicente, 11330-900 São Paulo, SP, Brazil

${ }^{3}$ Universidade Federal do Paraná, Setor de Ciências Biológicas, Avenida Cel. Francisco H. dos Santos, 100, 81530-000 Curitiba, PR, Brazil

Correspondence to: Murilo Zanetti Marochi E-mail:murilo.marochi@gmail.com

\section{Author contributions}

AT conceived the idea, methodology, data analysis, writing original draft. MZM contributed with methodology, formal analysis, preparation of tables and figures, writing - review \& editing. SM contributed with conceptualization, writing - review \& editing, supervision. All authors are involved in interpreting the results and developing the discussion section.

\section{(cc) BY}

